18. Доклад ПП ОГПУ по ЦЧО о контрреволюционных церковных и сектантских организациях и группах, ликвидированных ПП ОГПУ по ЦЧО в 1930 г. 15 октября 1930 г. // ЦА ФСБ. Ф. 2. Оп. 8. Д. 530. Л. 1-87.

19. Кузин К.И. К истории движения «Истинноправославных христиан» в Центральном Черноземье в конце 1920-х - 1960-е гг. // История российской духовности: материалы Двадцать второй всероссийской заочной научной конференции. СПб.: Нестор, 2001. C. $243-245$.

20. Дело по обвинению Черникова Бориса Сергеевича и др. // Государственный архив общественнополитической истории Воронежской области (ГАОПИВО). Ф. 9353, Оп. 2, Д. П-18214. Т. 1.
21. Дело по обвинению Маклакова М.М., Рубцовой А.Ф., Щербакова П.П., Заикина П.С., Ламзина В.Г., Щербаковой Д.И. по ст 58-10 ч. 2 и 58-11 УК РСФСР // ГАОПИВО. Ф. 9353, Оп. 2, Д.-26440.

22. Обвинительное заключение по делу № 3200 о контрреволюционной монархической организации филиала контрреволюционного центра «Истинноправославной церкви»» в Татарской АССР» [Электронный ресурс] // Из истории гонений ИстинноПравославной (Катакомбной) Церкви. - http://histoript-kt.org/DOK/Tatariya/D_32-3200.doc.

23. Воин Христов верный и истинный. Тайный епископ ИПЦ Михаил (Ершов). Жизнеописание, письма и документы / сост. И.В. Ильичев. М.: Братонеж, 2011. $744 \mathrm{c}$.

\title{
CAVES IN CATACOMB MOVEMENT OF THE RUSSIAN ORTHODOX CHURCH ON THE TERRITORY OF THE DON AND THE VOLGA REGION IN 1920-1940S
}

Stepkin Vitaliy Viktorovich, candidate of historical sciences, history teacher Pavlovskaya Secondary School (Pavlovsk, Voronezh Region, Russian Federation)

Gunko Aleksey Aleksandrovich, head of Spelestology and Kama Region Mining History Laboratory Naberezhnye Chelny State Pedagogical University

(Naberezhnye Chelny, Republic of Tatarstan, Russian Federation)

Abstract. The paper examines creation and application history of cave space in catacomb movement of the Russian Orthodox Church on the territory of the Don and the Volga Region in 1920-1940s. Development of cave digging on these territories was promoted by the fact of their frontier position, allowing searching for a «hiding place for the ideas, differing from the mainstream society». The caves use as shelters and places of worship in the Don Region is exemplified by the territory of Voronezh Region, where in the revolution period caves were dug in the chalk mass near the village of Karayashnik, and traditionally honored by the people loci of sacred space were used like caves in Divnogorye and on Shatrishche Mount. Caves near the village of Karayashnik were used as a place of worship by a conservative part of peasants being supporters of both the Patriarchal Church and the 'Fedorovtsy' sect. Caves in Divnogorye were used by Joanites sect, caves on Shatrishche Mount were used by so-called True Orthodox Church. In addition to the chalk caves in the Don Region people used underground of houses as secret places of worship. Examples of such undergrounds are hidden caves in the villages of Troitskoe and Novopokrovka, equipped by one of communities of so-called True Orthodox Christians. The paper considers caves use in the Volga Region through the example of the territory of the Republic of Tatarstan, where communities of the True Orthodox Church acted, creating cult undergrounds under houses in the town of Bugulma and villages of Akkireevo, Zabugorovka, Crym-Saray Naumovka and Novoe Ilmovo. Together with territories of personal farmsteads, caves were created outside villages, usually in a forest zone. For example, near the village of Novosheshminsk there was an underground monastery, near villages of Volchya Sloboda and Elantovo there were underground temples. Activities of the underground religious communities referred to in the paper were ceased due to state punitive measures.

Keywords: caves; Russian Orthodox Church; catacomb movement; True Orthodox Church; True-Orthodox Christians; 'Buevtsy' sect; 'Fedorovtsy' sect; Joanites sect; Don Region; Volga Region; frontier; village of Karayashnik; Divnogorye hole; Shatrishche hole; village of Volchya Sloboda; village of Elantovo; village of Novosheshminskoe.

УДК 323.28(470.56):93

Статья поступила в редакцию 25.12.2017

\section{ИСПЫТАНИЕ ПРОИЗВОЛОМ: 1937-1938 ГОДЫ}

(C) 2018

Федорова Алла Владимировна, доктор исторических наук, профессор кафедры истории и философии Оренбургский государственный аграрный университет (2. Оренбург, Российская Федерачия)

Аннотащия. Массовые политические репрессии 1920-1950-х годов имели для жизни общества и государства серьезные негативные последствия. Точной статистики политических репрессий в СССР не существует, хотя их масштабы чрезвычайно велики.

Статья посвящается не только жертвам репрессий, она ставит своей целью дать характеристику инициаторов, участников и исполнителей «операции по репрессированию». Именно в такой формулировке дан один из приказов НКВД № 00447 от 30 июля 1937 г.

В статье рассматриваются события, связанные с репрессиями 1937-1938 гг. в Оренбургской области, где первые аресты начались во второй половине 1936 г. Автор показывает, как сложившаяся командноадминистративная система, чудовищный судебный произвол, создание внесудебных органов для осуществления репрессий, торжество бесправия, обстановка беззакония и многое другое привело к массовым трагеди- 
ям. В центре внимания исследователя - уничтожение лучших партийных и советских кадров, капитанов индустрии, тысяч честных тружеников.

Автор статьи, кроме документов, извлеченных из фондов оренбургских архивов, привлекает воспоминания жертв произвола, а также материалы из личной переписки с их родственниками.

Российское государство осудило многолетний террор и массовые преследования собственного народа как несовместимые с идеей права и справедливости.

Ключевые слова: командно-административная система; репрессивная политика; массовые репрессии; «большой террор»; НКВД; Берия; правоохранительные и судебные органы; прокурор; следователь; Верховный суд СССР; враги народа; методы физического воздействия; судьбы репрессированных; Оренбургская область.

В последнее время раздаются голоса, утверждающие, что Сталин будто бы лично не является инициатором массовых репрессий, в том числе «большого террора» 1937-1938 гг. Однако архивные документы отчетливо демонстрируют инициативную роль Сталина в репрессивной политике. Заявления Сталина на февральско-мартовском Пленуме 1937 г. стали призывом к «большому террору». В статистике репрессий эти два года (1937 и 1938) занимают особое место, т.к. именно тогда наблюдался резкий скачок масштаба политических репрессий $[1 ; 2]$.

Исследователи основное внимание уделяют механизму беззаконного насилия, печальной статистике произвола, местам захоронений, горьким людским судьбам и т.д. [3-8]. В публикациях, посвященным репрессиям, много говорится об атмосфере 19371939 годов [9-13]. Путь в тюрьму, лагерь или к расстрелу предварялся доносом, арестом, следствием, судом. Исследователи и журналисты, как правило, останавливаются на теме доносов [14-17]. Менее всего анализу подвергаются деятельность органов следствия и суда. А ведь это они распахивали двери в ГУЛАГ.

Тема политических репрессий неоднократно затрагивалась оренбургскими исследователями и журналистами в небольших по объему статьях, но не получила своего развития.

Судьба арестованного зависела от трех значимых фигур - следователя, прокурора, судьи. Это подтверждают и сами представители правоохранительных органов. Вот что, к примеру, писал 23 августа 1937 года оренбургский прокурор Гольм: «Прокурорско-следственные работники Соль-Илецкого района в процессе ведения следствия не могли не сосредоточить своего внимания на показаниях отдельных лиц, допрашиваемых по делам, и на основании которых нельзя было не прийти к выводу о замаскированном вредительстве на основных участках социалистического строительства, проявляемом руководством района в лице секретаря районного комитета партии Костицина и председателя райисполкома Макарова».

Что только, говоря современным языком, не «навесили» Костицину и Макарову! Обратим внимание на один из пунктов: «Премирование председателя колхоза «Трудовой актив» Алехина велосипедом за производство им вредительского сена в колхозах». Другие пункты формулируются в аналогичном стиле.

Вывод прокурора Гольма прост и до боли ясен: «На основании изложенного прошу Костицина и Макарова исключить из партии, снять с работы и дать санкцию на их арест и предать суду». Кто же мог возразить прокурору? В условиях мощной пси- хологической атаки на население главной целью был поиск новых врагов и вредителей.

В расцвете сил, в возрасте сорока лет, погиб руководитель Соль-Илецкого района Оренбургской области Ф.С. Костицин. Спустя два десятилетия, 28 июля 1956 года его реабилитировали [18, с. 127]. Зададим вопрос: кто виноват в его гибели? Для нас он ясен: в первую очередь прокурор области Гольм. Занимая высокий служебный пост, он не счел нужным вникнуть в суть дела. Его беспринципность привела к расстрелу замечательного человека.

На арест Ф.С. Костицина, следствие, процесс и вынесение приговора местным, а потом и Верховным судом СССР ушло менее пяти месяцев. Вот у кого следует «поучиться» современным судьям, которые по оценке пленума Верховного суда РФ, данной еще в декабре 2007 года, ведут дела с «неоправданной задержкой», порой многолетней.

Установить фамилии следователей, судей и прокуроров - прямых участников террора - не составляет труда, однако в прессе осуждению подверглась только небольшая группа работников правоохранительных органов. Что касается большинства, то это еще дело будущего.

Автор статьи в 1989-1990 годах был свидетелем многочисленных встреч жертв политических репрессий, членов их семей, с одной стороны, и представителей местной власти областного уровня - с другой. В адрес руководства Оренбургского областного общества «Мемориал» $[19$, с. 3 ; 20, с. 3; 21, с. 3] сопредседателем которого я являлась [22, с. 2], к жертвам репрессий постоянно обращались с пламенными речами представители КГБ, УВД, Оренбургских облисполкома Совета народных документов, обкома КПСС с просьбой подумать о семьях сотрудников правоохранительных и судебных органов, которые совершили преступные деяния, чьи руки обагрены кровью тысяч и тысяч мучеников и страдальцев. Но почему? Разве они достойны большей жалости, чем невинно пострадавшие?

В известном докладе Н.С. Хрущева на ХХ съезде КПСС поставлена главная задача - обличение Сталина, его роли как вдохновителя массовых политических репрессий [23, с. 74-78]. Проблема личной ответственности была поднята год спустя на июньском (1957 г.) Пленуме ЦК КПСС. Известный полководец Г.К. Жуков также говорил о необходимости выявления и наказания всех виновных в массовых репрессиях.

Общество обязано делать выводы, извлекать серьезные уроки из прошлого. Следует признать, что тысячи следователей, прокуроров и судей, думая только о себе, о своей карьере, прогибались перед властями. Они фактически являлись исполнителями 
массовых политических репрессий. В их поступках усматривается корысть, моральная недобросовестность и просто трусость. И как бы они ни оправдывались, на них, в первую очередь, лежит страшная печать предательства своего народа, которое привело к гибели массы людей.

Кто испил ту горькую чашу, те помнят. Четверть века тому назад автор статьи записал воспоминания и собрал письма жертв репрессий, переживших зловейшие сталинские процессы. Г.Я. Чурилова, работавшего на Оренбургском комбикормовом заводе, обвинили в том, что он подсыпал песок в паровозы. Дали десять лет с правом переписки. В одном из писем, пришедшем из лагеря, он просил жену собрать документы, доказывающие его невиновность. Григорий Яковлевич писал, что он всю «напраслину взял на себя». «Напраслина» заключалась в том, что, будучи колхозником, до переезда в город, он якобы поджигал амбары с хлебом, служил в белой армии, подсыпал в паровоз песок и т.д.

Супруга М.Н. Чурилова собрала все нужные документы. В Переволоцком районе подтвердили, что в родном селе Чурилова давно ничего не горело, а однополчане отца написали о том, что Григорий Яковлевич не служил в белой армии, на паровозах не работал, трудился в основном на комбикормовом заводе. Долго супруга ходила по инстанциям, и наконецто правота Г.Я. Чурилова была признана, ей обещали, что муж скоро вернется. Но она его не дождалась: умер в лагере.

А.Г. Борзых, дочь Григория Яковлевича, пишет: «Да, мы тоже любили Сталина и других полководцев и плакали, когда умер Сталин. А теперь сердце разрывается, услышав о тех зверствах, которые наделали эти люди!»

В настоящее время известно, как выбивались признания. Сталин дал теоретическое обоснование допустимости пыток как исключительного средства в отношении явных врагов народа: «Применение методов физического воздействия в практике НКВД, начиная с 1937 года, разрешено ЦК ВКП (б). Известно, что все буржуазные разведки применяют методы физического воздействия против представителей социалистического пролетариата, и притом применяют эти методы в самой отвратительной форме. Возникает вопрос: почему социалистические органы государственной безопасности должны быть более гуманны по отношению к бешеным агентам буржуазии и заклятым врагам рабочего класса и колхозников? ЦК ВКП (б) считает, что методы физического воздействия должны как исключение и впредь применяться по отношению к известным и отъявленным врагам народа и рассматриваться в этом случае как допустимый и правильный метод». Данное «исключение» стало правилом.

Примеры жестокого обращения с заключенными содержатся, например, в директивном указании Прокурора СССР А.Я. Вышинского горпрокурорам Оренбургской области (№ 13/01534 от 13 марта 1937 г.) [24, л. 41].

Приказ Берии от 4 апреля 1953 г. подтверждал: «...в следственной работе органов МГБ имели место грубейшие извращения советских законов, аресты невинных советских граждан, разнузданная фальсификация следственных материалов, широкое приме- нение различных способов пыток: жестокое избиение арестованных, круглосуточное применение наручников на вывернутые за спину руки, продолжавшиеся в отдельных случаях в течение нескольких месяцев, длительное лишение сна, заключение арестованных в раздетом виде в холодный карцер и др.» [25, с. $35 ; 26$, л. 246].

Это объясняет отличительную особенность большинства процессов, на которых подсудимые сознавались в предъявленных им обвинениях. А. Ваксберг в связи с этим пишет: «Многим и в голову не могло прийти, что признание, заявленное на публичном суде, бывает отнюдь не только свободным и добровольным». Приведем весьма характерный, о многом говорящий эпизод. Один из бывших инженеров Бузулукского завода тяжелого машиностроения рассказывал, как на митинге, посвященном обсуждению постановления ЦК партии о культе личности Сталина в 1956 году, всех потрясло выступление рабочего К. Он не стал говорить о пережитом, а просто снял брюки и повернулся к присутствующим, извините, задом. А этого места-то не было, вместо него - привязанная подушка. Его пытали, посадив на включенную в сеть электроплитку. В довершение всего он тут же указал на своего мучителя, работавшего в это время на заводе в отделе кадров. Это не единственный случай, когда приходилось встречаться лицом к лицу палачу и жертве, доносчику и честному человеку, надзирателю и подследственному. Анна Ахматова пыталась предугадать, как встретятся две России. Одна - которая сажала, а другая - которая сидела. Как они посмотрят друг другу в глаза? По свидетельству известного оренбургского краеведа Г.М. Десяткова, его родной дядя, участник обороны Оренбурга Георгий Ефимович Михеев, отсидевший срок в лагерях, жил после реабилитации через стенку с оклеветавшим его.

В период «большого террора» Сталин фактически поставил карательные органы во главе государственной пирамиды. Достаточно сказать, что в 19371938 гг. Н.И. Ежов [27-29] был принят Сталиным в кремлевском кабинете (несомненно, были и другие встречи) 278 раз и провел в общении с «вождем» 834 часа [29, с. 207]. Только В.М. Молотов превзошел Ежова в общении со Сталиным. Культ НКВД, особое всевластное положение органов достигли в то время своего апогея.

Оренбургская областная печать в декабре 1937 года часто писала о работе особо «отличившихся» следователей. Всплывают оброненные жертвами или свидетелями имена истязателей: Циклин, Савицкий, Колесов, Зайцев, Богословский, Румянцев, Веселов, Краснов, Шлыгин, Шевелев, Портянкин и другие [18, с. 148].

Из оренбургских сотрудников НКВД в годы террора особенно отличился А.И. Успенский. В марте 1937 года сняли с должности начальника УНКВД по Оренбургской области Н. Райского, «не обеспечившего чекистской работы по области». На его место назначили А.И. Успенского, имевшего опыт «чекистской работы» с восемнадцати лет. До прибытия в Оренбург он занимал высокие посты: июль 1934 февраль 1935 - заместитель начальника Управления НКВД по Московской области, февраль 1936 - март 1937 - заместитель начальника Управления НКВД по 
Западно-Сибирскому краю. Перед назначением на новую должность в Оренбурге А.И. Успенского принял Народный комиссар внутренних дел СССР Н.И. Ежов, дав при встрече следующее указание «Не считаясь с жертвами, нанести полный оперативный удар по местным кадрам. Да, могут быть и случайности. Но лес рубят - щепки летят. Имей в виду, в практической работе органов НКВД это неизбежно. Главное, что требуется от тебя, - это показать эффективность своей работы, хорошие результаты, блеснуть внушительной цифрой арестов». Он и «блеснул».

За короткое время в Оренбуржье были сфальсифицированы десятки громких дел. На состоявшемся в июне 1937 года Всероссийском совещании руководства НКВД Н.И. Ежов поставил А.И. Успенского в пример многим. 25 января 1938 года Успенского назначили наркомом внутренних дел Украины. В этот же день ему присвоили звание комиссара государственной безопасности 3-го ранга. Успенский получил от Ежова санкцию на арест 36 тыс. человек. Через два года сатрапа постигла та же участь. 23 ноября 1938 г. Н.И. Ежов написал в своем прошении в Политбюро и лично Сталину об отставке, в котором признал себя ответственным за бегство в 1938 г. полпреда НКВД по Дальневосточному краю Генриха Люшкова в Японию и начальника УНКВД УССР А.И. Успенского, скрывшегося в неизвестном направлении. Успенского расстреляли 29 января 1940 года.

Газеты 1937-1938 гг. заполнены грозными заголовками: «Решительно бороться с предельщиками и саботажниками», «Троцкистский выродок», «Троцкистские последыши разоблачены», «Срывают маску с врагов», «Беспощадно разоблачать двурушников», «Приговор суда - приговор народа» и т.д. [30-35].

С первых дней октября 1937 года процессы в области приобрели массовый характер.

Начало октября - процесс над сотрудниками продснаба «Никельстроя», расстреляно 6 человек.

3 октября - суд над сотрудниками Буранной МТС, расстреляно 6 человек.

6-9 октября - процесс а Ново-Покровском районе, расстреляно 7 человек.

14-15 октября - суд над сотрудниками Сорочинского элеватора, расстреляно 3 человека.

31 октября - 1 ноября - процесс над работниками животноводства в Оренбурге, расстреляно 7 человек.

1-2 ноября - процесс над животноводами Домбаровского района, расстреляно 8 человек.

24-25 ноября - процесс над «вредителями» овцесовхоза «Караванный», расстреляно 5 человек.

27-28 ноября - процесс над животноводами совхоза «Овцевод» Каширского района, расстреляно 6 человек.

Кто же выносил эти решения? Оренбургские судьи А.И. Батраков, М.П. Стюарт, М.С. Федосов, П.И. Муравьев, А.К. Алехнович, Н.С. Шакуров. Дело «вредительской-террористической организации в Ново-Покровском районе» рассматривалось выездной сессией военного трибунала Приволжского военного округа в составе: председателя военного трибунала округа А.И. Микляева, членов военного трибунала, А.И. Верещагина, В.К. Колюцкого.

Все восемь подсудимых на этом процессе просили учесть искреннее раскаяние. Е.П. Киселев, пред- седатель Ново-Покровского райсполкома, сказал: «Прошу дать возможность честной работой загладить свою вину». Но приговор был «окончательным и обжалованию не подлежал». (Елизар Петрович Киселев, 1889 г.р. Приговорен к высшей мере наказания 9 октября 1937 г. Военным трибуналом Приволжского военного округа. Реабилитирован 21 июля 1956 г.) $[18$, c. $148 ; 32$, с. 2$]$.

И.В. Сталин еще в 1924 году говорил: «Мы... знали, что политика отсечения чревата опасностями для партии, что метод отсечения, метод пускания крови... опасен, заразителен, сегодня одного отсекли, завтра другого, послезавтра третьего, - кто же у нас останется в партии».

Но в 1937 году именно эта политика «отсечения» проводилась по всей стране. Были отброшены демократические принципы судебного производства, такие как объективность и всесторонность расследования и судебного рассмотрения уголовного дела, право обвиняемого на защиту.

Все обвиняемые в полной мере испытали на себе действия принятого 1 декабря 1934 года постановления «О порядке ведения дел по подготовке или совершению террористических актов», согласно которому срок следствия сокращался до 10 дней, обвинительное заключение обвиняемому следовало вручать за одни сутки до суда. Обжалование приговора и подача ходатайства о помиловании не допускались, приговор к высшей мере наказания должен приводиться в исполнении немедленно. Аналогичный порядок ввели 14 сентября 1937 года по делам о вредительстве и диверсии.

К этому списку следует добавить имена оренбургских прокуроров, виновных в репрессиях тысяч невинных людей. Доброе имя прокурорам, пострадавшим в 1937-1939 годах, таким как прокурор Беляевского района М.А. Дурачков, прокурор Тепловского района И.К. Черкасов, было возвращено. О них, например, можно прочитать в книге «Прокуратура Оренбуржья: история и современность», опубликованной в 2002 году, в подготовке которой участвовал и автор статьи.

Однако в данном случае речь идет о виновных в беззаконии и произволе. К ним, на наш взгляд, следует отнести прокуроров Оренбургской области Якова Павловича Коваленко, Владимира Евсеевича Сорокина, Леонида Михайловича Куроптева. Именно они возглавляли прокуратуру Оренбуржья с мая 1937 по июль 1939 года.

Следует согласиться с оценкой всего происходившего, данной ответственным секретарем комиссии при президенте РФ по реабилитации жертв политических репрессий В.П. Наумовым: «Тому, кто пытался определить самостоятельное отношение к политическим и экономическим явлениям в обществе, грозило физическое уничтожение. Проявления милосердия, гуманистических чувств вызывали столкновения с карательными органами. Это порождало готовность без рассуждений выполнить любой приказ, принять без размышления любую ложь, идущую от представителей власти, а это в свою очередь порождало двоедушие, апатию, цинизм, бездуховность» [25, с. 23].

В качестве подтверждения приведем только один пример. Во время суда над механизаторами Нежин- 
ской МТС Оренбургской области 29 августа 1937 г. «из 35 вызванных свидетелей ни один не привел ни одного факта в пользу обвиняемых» [36].

Точно подмечено - «готовность без рассуждений выполнить любой приказ». Доказательства находятся в архивах. К примеру, протоколы собраний партийных организаций, общегородских собраний членов и кандидатов ВКП (б), закрытых собраний райпартактивов, заседаний пленумов райкомов ВКП (б), заседаний бюро райкомов и т.д.

Протоколы 1937 года изобилуют списками врагов народа и отчетами о деятельности «по разоблачению и выкорчевыванию врагов народа». Анализ протоколов собраний Бузулукских районных парторганизаций и заседаний бюро Бузулукского райкома ВКП (б) Оренбургской области 1937 года отчетливо демонстрирует результаты мощной психологической обработки населения. В каждом протоколе одна единственная мысль: еще много предстоит работы «в выкорчевке врагов народа» [37].

Собрания использовались в качестве одного из рычагов упрочения репрессивной политики. Разного рода активы, партийные, комсомольские, профсоюзные собрания становились нередко ареной драматических столкновений, методом запугивания, морального террора.

Один из выступающих на отчетно-выборном собрании парторганизации Буранного района Оренбургской области, состоявшемся 15-17 мая 1938 г., заявил: «...Была создана такая обстановка, когда люди, видящие неправду в обвинении коммуниста, молчали, потому что боялись привлечения к ответственности как защитника пособника» [38, л. 7].

Несмотря на угрозу жестоких наказаний, люди оказывали друг другу помощь. Широкое распространение получили тогда коллективные ходатайства за арестованных. Как правило, ни к какому результату они не приводили, однако коллективные ходатайства продолжали поступать.

В декабре 2017 г. отметила свое 90-летие жительница г. Оренбурга Г.Я. Лащёнова. На юбилейном вечере присутствовала, кроме родственников, семья Коростылёвых, чьи родители в далеком 1937 г., не побоявшись преследования, приютили у себя мать Г.Я. Лащёновой с шестью детьми. Главу семейства Я.К. Будкова арестовали 24 августа 1937 г. в c. Разномойка Троицкого района Оренбургской области как врага народа и спустя некоторое время 11 октября 1937 г. - расстреляли в Зауральной роще $[18$, с. 51$]$. И таких примеров было немало.

Страх или подлость заставляли людей преступать «грань нравственных запретов». Вчерашние друзья и коллеги в гневе обрушивали друг на друга грязные обвинения, что усиливало страх и безверие. Тем благороднее были выступления противостоящих «истерии страха и доносов».

Восемь десятилетий прошло после сталинских репрессий. Однако и сегодня средства массовой информации передают, публикуют разнообразные материалы о нарушении законности в нашей стране со стороны правоохранительных органов и судебной системы, на которые неоднократно обращал внимание президент Российской Федерации В.В. Путин.

\section{Список литературы:}

1. Данилов В.П. Сталинизм и советское общество // Вопросы истории. 2004. № 2. С. 169-175.

2. Кропачев С.А. Потери населения СССР в $1937-$ 1945 гг.: масштабы и формы. М.: РОССПЭН, 2012. $348 \mathrm{c}$.

3. Ваксберг А. Царица доказательств. Вышинский и его жертвы. М.: Книга и бизнес, 1992. 351 с.

4. Гордон Л.А. Что это было? Размышления о предпосылках и итогах того, что случилось с нами в 30-40-е годы. М.: Политиздат, 1989.318 с.

5. Гинзбург Е.С. Крутой маршрут: хроника времен культа личности. М.: Сов. писатель, 1990. 608 с.

6. Берия: конец карьеры / ред. В.Ф. Некрасов. М.: Политиздат, 1991.414 с.

7. Неймарк Н. Геноциды Сталина. М.: АИРОXXI, 2012. $176 \mathrm{c}$.

8. Викторов В.В. Культ личности в России: попытка осмысления. М.: ИНФРА-М, 2016. 208 с.

9. Реабилитация. Политические процессы. 30-50х г. / сост. И.В. Курилов. М.: Политиздат, 1991. 460 с.

10. Наринский А.С. Время тяжких потрясений. СПб.: Изд-во СПб. ун-та экономики и финансов, 1993. $168 \mathrm{c}$.

11. Орлов А. Тайная история сталинских преступлений. М.: Автор, 1991. 351 с.

12. Хлевнюк О.В. 1937-й: Сталин, НКВД и советское общество. М.: Республика, 1992. 270 с.

13. Эпплбаум Э. ГУЛАГ: Паутина Большого терpopa. М.: Моск. шк. полит. исслед., 2006. 608 с.

14. 1937-й и другие годы. Воронеж. Центр.-Чернозем. кн. изд-во, 1990. 288 с.

15. Чирков Ю.И. А было все так ... Моим товарищам посвящается. М.: Политиздат, 1991. 382 с.

16. Гурковский А.Н. Вспоминая 1937 год // Военно-исторический журнал. 2006. № 8. С. 52-56.

17. Север А. Тайна сталинских репрессий. М.: Алгоритм, 2007. $272 \mathrm{c}$.

18. Книга памяти жертв политических репрессий в Оренбургской области. Оренбург: Печат. Дом «Димур», 2010. $416 \mathrm{c}$.

19. Федорова А.В. Дела и планы «Мемориала» // Южный Урал. 1989. 28 октября. С. 3.

20. Федорова А.В. КГБ и «Мемориал»: деловые контакты // Южный Урал. 1989. 22 ноября. С. 3.

21. Неделя совести // Южный Урал. 1989. 26 ноября. С. 3.

22. Южный Урал. 1989. 1 января. С. 2.

23. Пожаров А.И. Роль личности в истории сталинских репрессий // Закон и право. 2002. № 12. C. 74-78.

24. Государственный архив Оренбургской области. Ф. Р-1308. Оп. 1. Д. 20. Л. 41.

25. Наумов В.П. Н.С. Хрущёв и реабилитация жертв массовых политических репрессий // Вопросы истории. 1997. № 4. С. 19-35.

26. Государственный архив Российской Федерации (ГАРФ). Ф.Р-9401. Оп. 1. Д. 1299. Л. 246.

27. Ковалев В.А. Два сталинских наркома. М.: Прогресс, 1995. 319 c.

28. Полянский А.И. Ежов. История «железного» сталинского наркома. М.: Вече, 2001. 400 с.

29. Jansen M. and Petrov N. Stalin`s Loyal Executioner: People`s Commissar Nikolai Ezhov. 1885-1940. Stanford, California. Hoover Institution press, 2002. $274 \mathrm{p}$. 
30. Решительнее бороться с предельщиками и саботажниками // Большевистская смена. 1937. 20 января.

31. Шутов А. Троцкистский выродок // Большевистская смена. 1937. 4 марта.

32. Алексеев В. Троцкистские последыши разоблачены // Большевистская смена. 1937. 6 апреля.

33. Орлов А.В. Срывают маску с врагов // Большевистская смена. 1937. 9 августа.
34. Отвалов Л. Беспощадно разоблачать двурушников // Большевистская смена. 1937. 27 августа.

35. Дорофеева. Приговор суда - приговор народа // Большевистская смена. 1937. 12 сентября.

36. Оренбургская коммуна. 1937. 1 сентября.

37. Центр документации новейшей истории Оренбургской области (далее ЦДНИОО). Ф.969. Оп. 3. Д. 346.

38. ЦДНИОО. Ф. 132 6. Оп. 1. Д. 44. Л. 7.

\section{A TEST BY THE ARBITRARINESS IN 1937-1938}

(C) 2018

Fedorova Alla Vladimirovna, doctor of historical sciences, professor of History and Philosophy Department Orenburg State Agrarian University (Orenburg, Russian Federation)

Abstract. Mass political repressions of the 1920s-1950s had serious negative consequences for the life of society and the state. Accurate statistics of political repression in the USSR does not exist, although their scale is extremely large. The author's paper is dedicated to the victims of repression as well as it gives a description of the initiators, participants and executors of the «operation on repression». One of the orders of the NKVD № 00447 of July 30, 1937 contained this word combination. The author considers events related to the repression of 1937-1939 in the Orenburg Region, where the first arrests began in the second half of 1936. The author shows how the established command and administrative system, monstrous judicial arbitrariness, creation of extrajudicial bodies for repressions implementation, the triumph of lawlessness, the state of lawlessness and much more led to mass tragedies. The focus of the researcher is the destruction of the best party and people, industry captains, thousands of honest workers. The author in addition to documents extracted from the Orenburg archives, attracts memories of victims of arbitrariness, as well as materials from personal correspondence with their relatives. The Russian state condemned the long terror and mass persecution of its people as incompatible with the idea of law and justice.

Keywords: command and administrative system; repressive policy; mass repressions; Great Terror; NKVD; Beria; law enforcement and judicial bodies; prosecutor; investigator; Supreme Court of USSR; enemies of people; physical assault methods; fate of repressed; Orenburg Region.

УДК 908(470.43)

Статья поступила в редакцию 10.01.2018

\section{ГЕРОИ СОВЕТСКОГО СОЮЗА - СТУДЕНТЫ КУЙБЫШЕВСКОГО ГОСУДАРСТВЕННОГО ПЕДАГОГИЧЕСКОГО ИНСТИТУТА (ПО МАТЕРИАЛАМ АРХИВА СГСПУ И СОГАСПИ)}

(C) 2018

Храмкова Елена Ленаровна, доктор исторических наук, профессор кафедры отечественной истории и археологии Храмкова Нина Петровна, кандидат исторических наук, профессор кафедры отечественной истории и археологии Самарский государственный соџиально-педагогический университет (2. Самара, Российская Федераџия)

Аннотация. Весной и летом 2017 г. в архиве Самарского государственного социально-педагогического университета были обнаружены личные дела Героев Советского Союза Владимира Михайловича Михеева, Александра Митрофановича Бондарева и Александра Васильевича Новикова. Их имена и подвиги, совершенные в период Великой Отечественной войны, были давно и хорошо известны. Однако благодаря новым документам их удалось впервые связать с педагогическим вузом и историческим факультетом, который они успешно окончили после войны. Установленные факты нашли подтверждение и в документах Самарского областного государственного архива социально-политической истории. 7 ноября 2017 г. на здании СГСПУ (ул. Л. Толстого, 47) установили мемориальную доску с изображениями героев и указанием дат их обучения в педагогическом институте. В ноябре-декабре этого же года в архиве СГСПУ были найдены еще два личных дела - Героев Советского Союза Бориса Михайловича Падалко и Михаила Яковлевича Романова, также окончивших заочное отделение исторического факультета. Обнаруженные материалы вновь были подтверждены материалами СОГАСПИ. Началась работа, направленная на реконструкцию довоенных, военных и послевоенных биографий героев.

В статье впервые на основе личных дел, хранящихся в архиве СГСПУ и СОГАСПИ, рассмотрены известные, малоизвестные и новые факты жизни и деятельности пяти Героев Советского Союза 1941-1945 гг. студентов первых послевоенных наборов Куйбышевского педагогического института. Удалось не только увеличить количество героев, обучавшихся в вузе, но и число Героев Советского Союза Самарской области.

Ключевые слова: Герои Советского Союза; Великая Отечественная война; архив Самарского государственного социально-педагогического университета; Самарский областной государственный архив социально-политической истории; личные дела; Куйбышевский государственный педагогический институт; исторический факультет. 